Año LII urtea

N. ${ }^{\circ}$ 94. zk.

2020

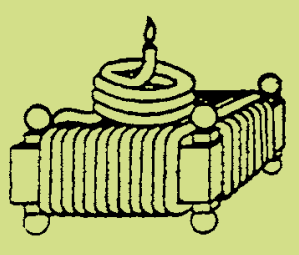

\section{CUADERNOS de Etnología y Etnografía de Navarra}

SEPARATA

\title{
El lecayo, una soka-dantza del siglo XVI
}

Ricardo Urrizola Hualde 


\section{Sumario / Aurkibidea}

\section{Cuadernos de Etnología y Etnografía de Navarra}

Año LII urtea - N. ${ }^{\circ}$ 94. zk. - 2020

\section{ARTÍCULOS/ARTIKULUAK}

Etxe izen zizelkatuak. Ageriko idazkunak etxeetan eta hilobietan

Koldo Colomo Castro

Recardera, oficio de mujer

Ricardo Gurbindo Gil

Aralar mugarriturik (1523-1857)

Jose Luis Erdozia Mauleon

El lecayo, una soka-dantza del siglo XVI

Ricardo Urrizola Hualde

El recuerdo público de una muerte política: historiografía periodística y etnografía de la ritualidad pública (José Luis Cano Pérez, 1949-1977)

Kepa Fernández de Larrinoa, Karlos Irujo Asurmendi, Santiago Martínez Magdalena, Txuri Ollo Gorriti, Cristina Saura Blanco

El Camino de Santiago en Navarra en 1971 a la luz de un informe para su mejora elaborado por la Dirección de Turismo, Bibliotecas y Cultura Popular Fernando Vega López

Reformulación del discurso significativo sociocultural en el entramado fortificado de la Línea P (Valle de Roncal-Navarra) 


\section{Sumario / Aurkibidea}

NOTICIAS/BERRIAK

Joxe Ulibarrena y su pasión por la Etnografía

Elur Ulibarrena Herce

Normas para la presentación de originales / Idazlanak aurkezteko arauak / 


\section{El lecayo, una soka-dantza del siglo XVI}

Lekaioa, XVI. mendeko soka-dantza

The Lecayo, a 16th century soka-dantza

Ricardo URRIZOLA HUALDE

Investigador

arbizuar@hotmail.com

DOI: https://doi.org/10.35462/CEEN94.4

Recepción del original: 13/10/2020. Aceptación provisional: 6/11/2020. Aceptación definitiva: 14/12/2020. 


\section{RESUMEN}

Se trata aquí sobre cuatro referencias históricas a una danza que durante los siglos XVI y XVII se conocía como la danza del lecayo. Por los testimonios de varios testigos de la época, se puede deducir que el lecayo era una danza que se podía bailar en pareja o en corro abierto con mucha gente. Además de la danza lecayo, en el presente artículo se dan testimonios sobre otra danza de origen medieval, conocida como morisca, y de una danza definida por los danzaris como "saltar de corrida", bailada en Irurita en el año 1572, lo que podría ser la referencia más antigua a una danza de saltos en Euskal Herria.

Palabras clave: lecayo; danza; morisca; Irurita; Eibar.

\section{LABURPENA}

Testu honetan, XVI eta XVII. mendeetan lekaioaren danza bezala ezagutzen zen dantza bati buruzko lau erreferentzia historiko aztertzen dira. Garai hartako hainbat lekukoren testigantzei esker, lekaioa bikoteka edota jende askorekin batera dantzatu zitekeen dantza bat zela ondoriozta daiteke. Dantza honez gain, artikulu honetan alde batetik Erdi Aroko beste dantza bati buruzko lekukotzat ematen dira, moriska bezala ezagutzen dena, eta bestetik dantzariek 1572an Iruritan dantzatutako korrikaldiko jauzia bezalako dantzaren gainekoak, Euskal Herriko jauzi-dantza baten erreferentziarik zaharrena izan zitekeena.

Gako hitzak: lekaio; dantza; moriska; Irurita; Eibar.

\section{ABSTRACT}

This text analyzes four historical references to a dance that during the 16th and 17th centuries was known as the dance of the lecayo. From the testimonies of several with esses of the time, it can be deduced that the lecayo was a dance that could be danced in pairs or in open circle with many people. In addition to the lecayo dance, in this article testimonies are given about an other dance of medieval origin, known as morris dance, and another dance defined by the dancers as jumping, danced in Irurita in the year 1572, which could be the oldest reference to a jump dance in Euskal Herria.

Keywords: lekaio; dance; morris dance; Irurita; Eibar. 
1. InTROduCción. 2. LA DANZA LeCAYO. 2.1. Febrero de 1560, Sarriguren. 2.2. Fiesta de la Ascensión de 1572, Irurita. 2.3. Día de la Ascensión de 1585, Irurita. 2.4. Romería de Arrate de 1620, Eibar. 3. Significado de lecayo. 4. ConClusiones. 5. Lista de REFERENCIAS.

\section{INTRODUCCIÓN}

Los orígenes de la soka-dantza parecen encontrarse en ese baile practicado en la Europa medieval conocido como carola ${ }^{1}$. Ambas danzas, soka-dantza y carola, comparten características fundamentales en su ejecución: se bailan en corro abierto y participan hombres y mujeres que se dan la mano al ejecutar la danza. En ambas también la figura del guía de la danza es de gran importancia².

Las primeras noticias sobre carolas en el contexto europeo las encontramos en el siglo XIII, identificadas con una danza cortesana o danza baja ${ }^{3}$. Martínez de Lagos (2007, p. 155) apunta a una talla en piedra de la iglesia románica de Brindisia (Italia), como la representación conocida más temprana de esta danza. Ya en la península, y siguiendo a la misma autora, se conocen dos menciones sobre carolas en dos textos del

1 Sánchez Ekiza en: http://aunamendi.eusko-ikaskuntza.eus/es/soka-dantza/ar-110609/.

2 La palabra carola deriva del carole francés, y esta del choraules latín. Según el diccionario Espasa (1978), la carola es una «danza medieval, acompañada generalmente de canto, que fue muy popular en Francia e Inglaterra, donde su nombre ha quedado en la forma de carol, para designar cantos populares o de navidad».

3 Quintanilla (2018, p. 250) define a la danza baja como de «lentitud y precisión, prefiriendo los pasos marcados y deslizantes frente a los saltos y golpes de los pies sobre el suelo de los plebeyos» y contrapone «las danzas campesinas, democráticas, sin conductores fijos y habitualmente circulares» con las danzas bajas, «que adoptan la forma de procesión. El rango ocupado en la danza corresponde al que se ocupa en la sociedad». 
siglo XIII, la primera en una traducción de ese siglo del Cantar de los Cantares, y la segunda en los Milagros de Nuestra Señora, escritos por Gracián de Berceo hacia $1250^{4}$.

En Navarra tenemos varias representaciones de carolas en edificios religiosos, todas ellas fechadas en la Baja Edad Media ${ }^{5}$. La más completa sería la que se conserva en uno de los capiteles que adornan la crujía este del claustro de la catedral de Iruñea ${ }^{6}$ (fig. 1). Otros edificios religiosos de Navarra con carolas en su decoración serían la ermita de San Zoilo, en Cáseda (fig. 2), y la parroquia de San Julián y Santa Basilisa, en Andosilla (fig. 3).

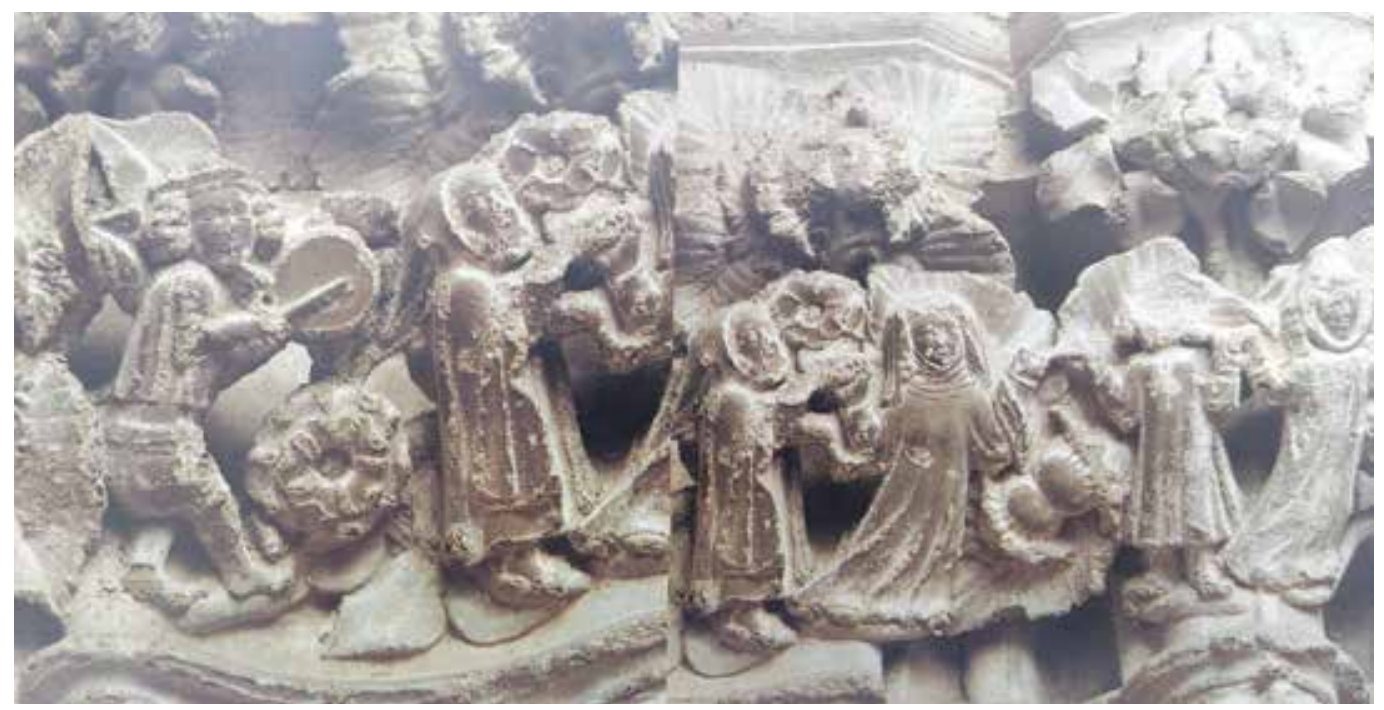

Figura 1. Carola situada en uno de los capiteles del ala este del claustro de la catedral de Iruñea. Fuente: Jusué (1994, p. 279).

4 En esta obra aparece la palabra carola escrita como «quirola», lo que dio pie a relacionar carola con kirola, y kirola con «alegría, regocijo y fiesta» (Tovar \& Agud, 1993, p. 1006).

5 Félix Rivas, en su estudio sobre la iconografía musical de Aragón, señala que «durante el periodo románico aparecen casi exclusivamente las figuras sueltas, representando por tanto un tipo de baile profesional. Conforme avanza la Baja Edad Media son mucho más comunes las representaciones de carola cuya finalidad sería el divertimento y disfrute de los propios participantes» (Rivas, 2002, p. 39).

6 La descripción de este conjunto danzari la da Martínez de Lagos (2007, pp. 155, 156): «abre la danza un juglar joven de pelo rizado, vestido con calzón corto y que porta una especie de zurrón colgando de su hombro, va descalzo y tañe una flauta y un tamboril. El primer danzante es un hombre barbado vestido con sayo largo y que lleva la cabeza cubierta con un capirote, le sigue una dama de larga saya y cabeza cubierta por tocado de la época que enlaza su mano con el danzante al que le falta la cabeza, [...] este a su vez une su mano con la de la segunda dama de esta representación [...]. El ultimo danzante, también mutilado y sin cabeza, es un caballero puesto que se aprecia su cinturón y la espada que cuelga del mismo. Una mano la lleva enlazada con la dama que le precede y la otra la tiene reposada en su cintura, actitud muy propia de los bailes cortesanos de este época, ya que cierra esta danza coral abierta. Todos ellos elevan sus manos enlazadas a una altura comprendida entre los hombres y la cabeza y parecen bailar de una forma elegante y sosegada muy lejana a la actitud de las danzas desenfrenadas». 


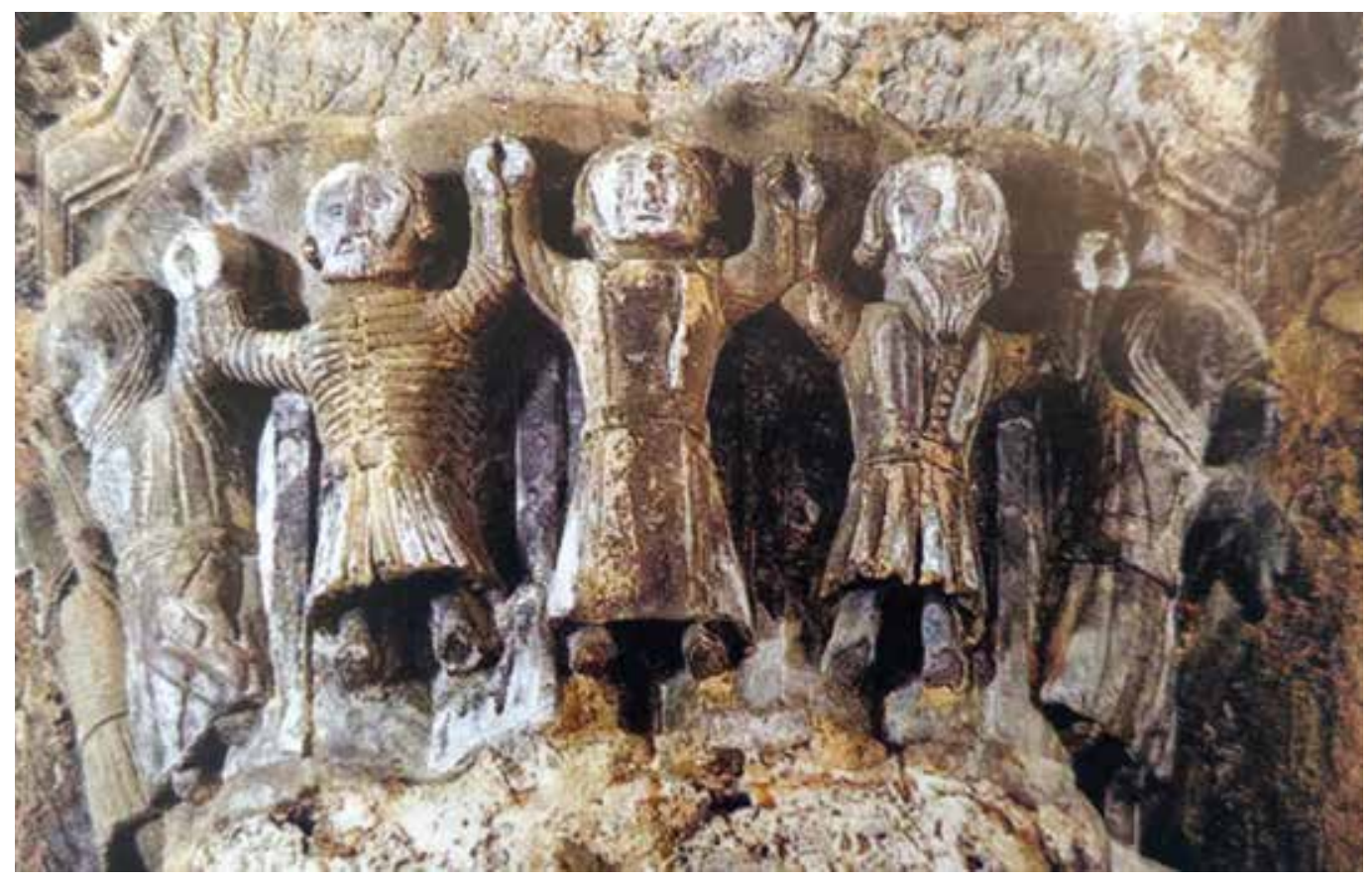

Figura 2. Carola mixta en la ermita de San Zoilo, Cáseda. Fuente: Sola (2010, p. 131).

Saliendo del ámbito religioso, el palacio de Óriz albergaba en su decoración otra representación de carola, aunque en este caso su fecha de ejecución se establece hacia la segunda mitad del siglo XVI (figs. 4 y 5). Como veremos más adelante, este friso se podría relacionar con un tipo de baile que estaba muy de moda en Navarra durante aquel siglo, la morisca. El conjunto danzari, hoy conservado en el Museo de Navarra, se compone de «un corro de niños desnudos, que danzan enlazados por cintas a las que van cosidos

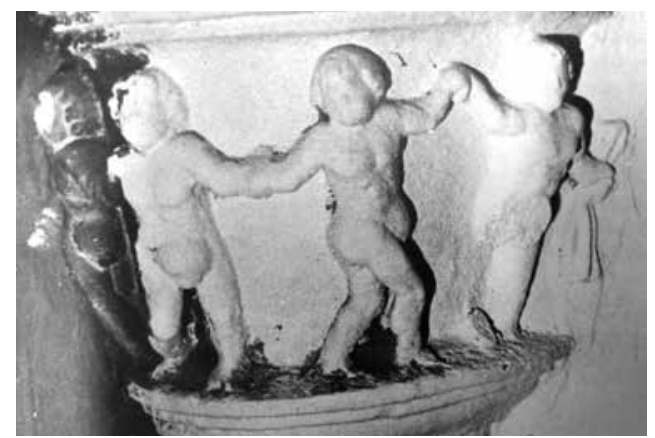

Figura 3. Carola en una nave de la ermita de San Julián y Santa Basilisa, Andosilla. Fuente: Alonso y Napal (1991, p. 135). cascabeles» (Sánchez, 1944, p. 25).

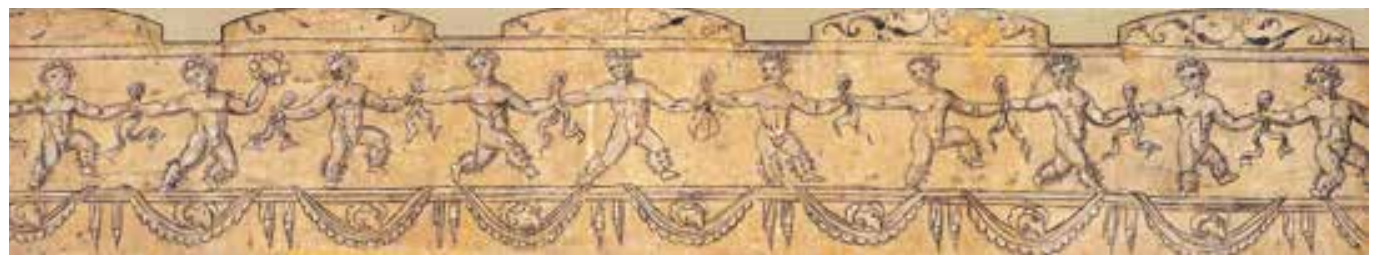

Figura 4. Danzaris unidos por cintas, desnudos y con cascabeles en los tobillos; parte del friso que decoraba el palacio de Óriz, hoy en el Museo de Navarra. Fuente: Museo de Navarra. 


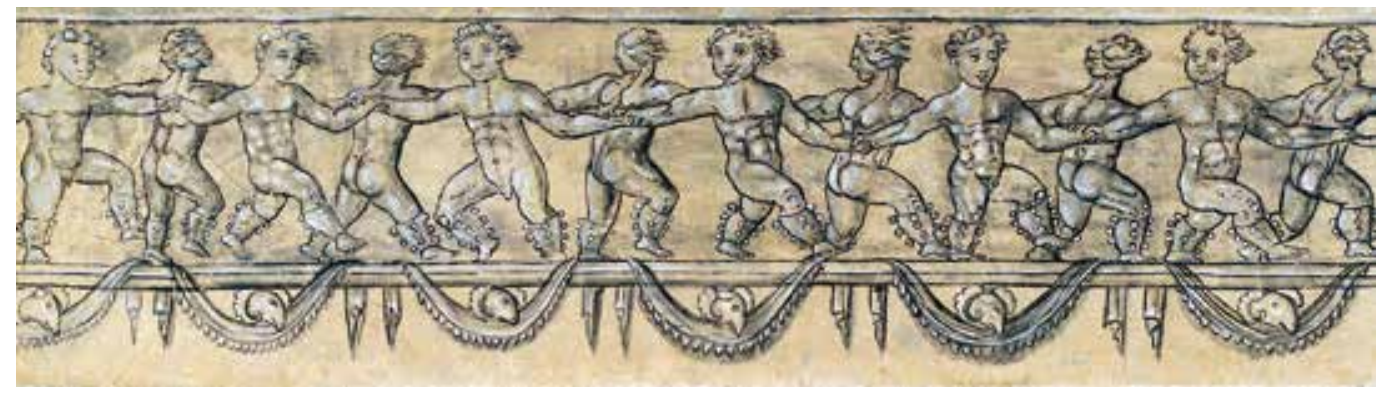

Figura 5. Danzaris desnudos agarrados por las manos. Fuente: Museo de Navarra. Característica común en estas escenas, y en las de la ermita de San Zoilo y la iglesia de Andosilla, es que los componentes del corro bailan siempre cara al exterior.

\section{LA DANZA LECAYO}

Por la información que aportan los cuatro documentos encontrados que tratan sobre la danza lecayo (tres procesos judiciales incoados en Iruña y un acta notarial de Eibar), se puede afirmar que esta danza sería un tipo de baile muy conocido y practicado en buena parte de Vasconia durante los siglos XVI y XVII.

En el primer documento, un pleito sobre unos incidentes ocurridos en Sarriguren la noche de carnaval de 1562, la referencia al baile lecayo la suministra una muchacha del pueblo, al afirmar que, esa noche, había bailado un lecayo formando pareja con un juglar en la puerta de su casa. Este es el único caso en donde la danza se baila en pareja.

Las siguientes referencias a la danza lecayo se encuentran en sendos pleitos incoados en Irurita, uno en 1572 y el siguiente en 1585. Los testimonios de los vecinos hablan de una danza en corro, mixta, formada por unas cuarenta personas y con sus participantes cogidos de la mano. En 1572, la danza fue capitaneada por un sacerdote y varias palacianas de la zona.

El último caso localizado de una danza lecayo se sitúa en 1620 en la ermita de Arrate de Eibar. La danza, en corro abierto, estuvo protagonizada ese día por cuarenta personas, todos varones?

En los casos de Eibar y de Irurita, y gracias a los testimonios de los testigos, la identificación entre danza lecayo y una primitiva soka-dantza es más que evidente.

7 En el grabado del siglo XVIII sobre la ermita de Arrate y su entorno, se puede apreciar, entre otros detalles, una escena de danza en corro abierto que bien pudiera una danza lecayo. La ejercitan hombres y mujeres (capitanea la danza una mujer) y están acompañados por varios músicos. Dos hombres, en actitud señorial, vigilan al grupo danzari. 


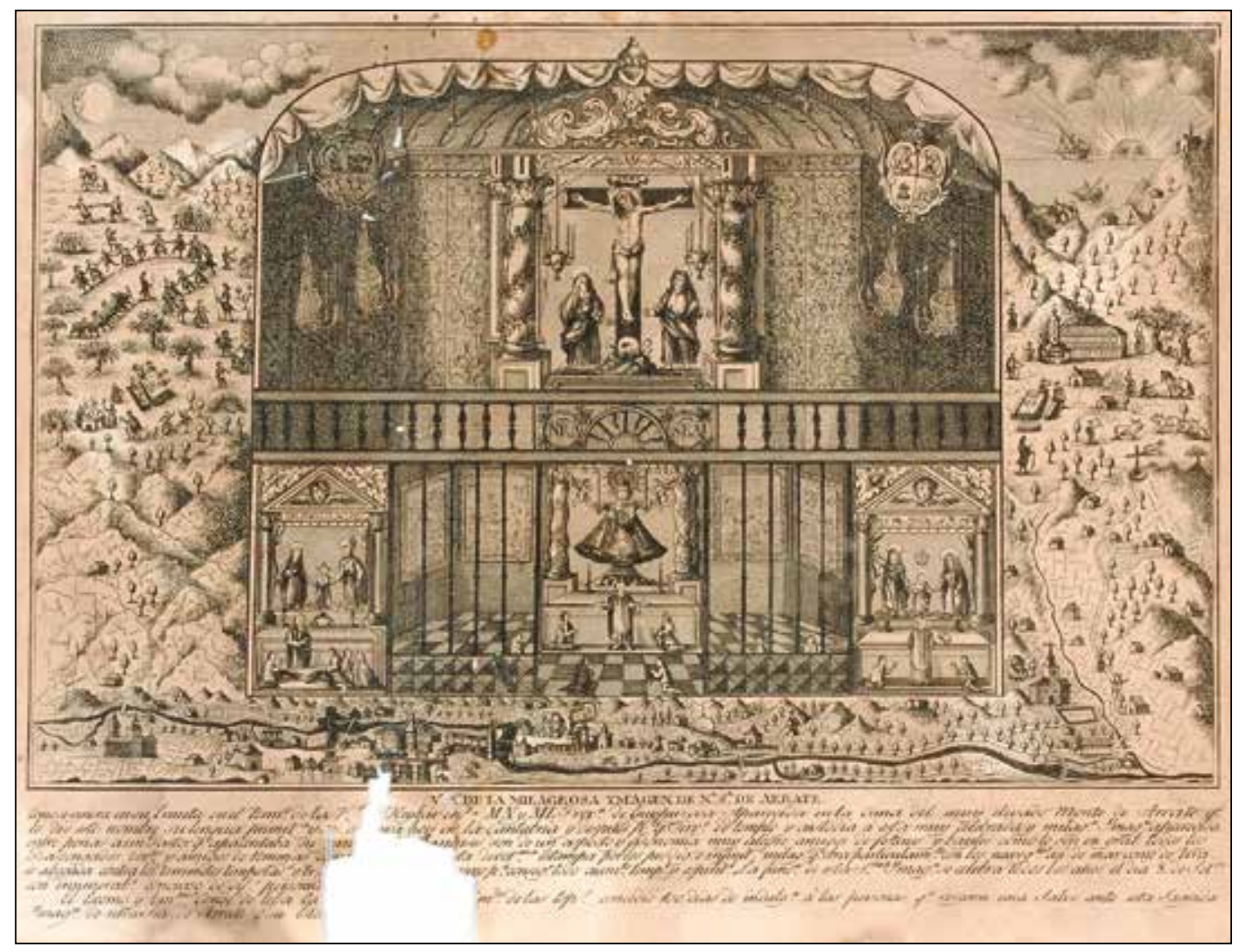

Figura 6. Grabado dedicado a la virgen Milagrosa de Arrate. La imagen de la danza se puede apreciar en su lateral izquierdo superior. Fuente: Museo de San Telmo, Donostia.

\subsection{Febrero de 1560, Sarriguren}

Siguiendo un orden cronológico de los casos, la primera referencia al baile lecayo la encontramos en Sarriguren, entonces un pequeño pueblo de la comarca de Pamplona.

El sábado previo al domingo de carnaval de 1560, varios mozos de Mendillorri contrataron a un juglar, residente en Iruñea, para que les hiciese música en la ronda nocturna que habían programado para esa noche. Mozos y juglar salieron de ronda desde Mendillorri hasta Olaz, haciendo parada en Sarriguren. A la mañana siguiente, domingo de carnaval, recién amanecido, los mozos regresaban sin dormir a Mendillorri, pero al llegar a Sarriguren una cuadrilla les estaba esperando con palos y espadas en la mano. Se querían vengar por el alboroto de la noche anterior. En el calor de la disputa, el juglar sacó su espada y le cortó dos dedos de la mano a Joanicot Martigena, el vecino de Sarriguren que presentó la denuncia ante los tribunales del reino.

En su declaración ante el juez, Joanicot, de sesenta años, afirmaba que la cuadrilla que vio pasar por Sarriguren el sábado por la noche fue la misma que pasó el domingo por la mañana: 
[...] fueron al lugar de Sarriguren a dar músicas y danzas de cascabeles aquella mañana, que los vio con los aparejos de ello, como en la noche de antes, después de noches, yendo este testigo a acostar sintió las mismas danzas y música, y por lo que vio el domingo [...] tiene por cierto que eran ellos mismos los que anduvieron así a prima noche, como a la alborada, con los cascabeles y con su salterio y flauta ${ }^{8}$.

Joanicot relataba al juez que el domingo, cuando vio discutir a los de Mendillorri con los vecinos de Sarriguren, se acercó con un palo para «apaciguar la cuestión». El resultado fue el siguiente:

con una de las cuchilladas me acertaron y dieron en la mano izquierda, [...] me derribaron luego uno de [los dedos] en el suelo, y los nervios y huesos de los otros, de que me salió mucha efusión de sangre, y quedé baldado y manco de la mano, y dejándome ellos por muerto huyeron y se fueron de alli19.

El juglar se llamaba Martín Arangozqui. Tenía treinta y dos años. Se declaraba natural de Baja Navarra (vascos) y vecino de Pamplona. Declaraba ante el juez que los mozos de Mendillorri le contrataron la misma noche del sábado para «dar alboradas [...] con sus cascabeles». Tras prestar declaración fue conducido a prisión junto con otro mozo de Mendillorri ${ }^{10}$.

Días después, el abogado del juglar presentó para testificar a varias mozas de Olaz. En sus testimonios, afirmaban que la cuadrilla de Mendillorri y el juglar no llevaban armas. Una de ellas, Mari Miguelt, hija del molinero de Olaz, de veintidós años, fue la que aportó la noticia de la danza lecayo:

8 Archivo General de Navarra - Nafarroako Artxibo Orokorra [en adelante AGN-NAO], Tribunales Reales, Procesos, n. ${ }^{\circ} 010414$, f. 2 r.

El testimonio más temprano sobre la utilización de cascabeles en una danza en Navarra, aunque no en las piernas sino en las mangas, nos lleva al año 1531. El último día de abril de ese año, en la celebración por una boda en Pamplona, varios mozos amigos de la novia quisieron organizar una danza al anochecer. Para ello pidieron licencia al teniente de justicia y más tarde al propio justicia. El primero la concedió pero el segundo no. La noche terminó en altercados y los jóvenes procesados. Estos, en sus testimonios ante el juez, declaraban que "por regocijo de la fiesta y solemnidad de los desposorios determinamos de hacer una danza de cascabeles, sin intención de dañar a nadie». El testimonio con más información fue el siguiente: «acordaron danzar por las calles de Pamplona por tomar placer, y yendo con esta pretensión, llevando sus cascabeles en las mangas, toparon al justicia de Pamplona, que andaba rondando por la ciudad casi a las nueve de la noche [...]; los compañeros iban con dos hachas y sus caras descubiertas, y algunos de ellos sin espadas [...] y el justicia les respondió que no era tiempo conveniente para ello». (AGN-NAO, Tribunales Reales, Procesos, n. ${ }^{\circ} 000101$, sin foliar).

9 AGN-NAO, Tribunales Reales, Procesos, n. ${ }^{\circ} 010414$, f. 1 r.

10 Las notificaciones a los testigos del juicio, redactadas en castellano, tuvieron que traducirse al euskera porque ninguno de los testigos sabía castellano. A Martín, alias Xuri, vecino de Mendillorri, se le comunicó "la provisión real [...] declarándole en bascuence todo lo en ella contenido»; al criado Joanicot se le notificó el requerimiento «en la casa de Mendillorri, cabo la iglesia [...] declarándole a alta e inteligible voz en bascuence todo lo en ella contenido, el cual oído y comprendido dijo y respondió que se tenía por intimado». El juglar Martín Arangozqui y su compañero de prisión tampoco sabían expresarse en castellano. A ambos, antes de declarar ante el juez, se les leyó la acusación que pesaba contra ellos «en bascuence, y después que la hubieron oído y comprendido lo en ella contenido respondieron» (AGN-NAO, Tribunales Reales, Procesos, n. ${ }^{\circ} 010414$, ff. $\left.5 \mathrm{v}, 6 \mathrm{v}\right)$. 
fueron al lugar de Olaz los acusados, juntamente con Martín de Ozcariz y Joanicot vasco a tañer a la casa del padre de esta que depone, y estuvieron en ella tañendo, y esta testigo danzó con Joanicot vasco una morisca ${ }^{11}$ y un lecayo, y después de acabado de danzar, esta que depone les dio de colación, y con tanto se fueron [...] sin que llevasen armas algunas ${ }^{12}$.

\section{El resto de testimonios confirmaban lo dicho por Mari. Como Juana Esparza:}

no les vio, a los acusados ni a sus compañeros, que llevasen ningunas armas [...] porque les dio de colación dentro en su casa, y después de que hubieron hecho colación se fueron hacia Olaz a hacer música tañendo con cascabeles y con un atabal ${ }^{13}$.

11 La morisca fue una danza muy popular en Europa durante los siglos XV y XVI. Arbeau, en su libro Orchésographie (1589), la describe así: «en buena sociedad, después de comer, entraba en la sala un jovencillo enmascarado y tiznado, ceñida la frente con un tafetán blanco o amarillo, el cual con calzones de cascabeles danzaba la danza de los Moriscos, y caminando a lo largo de la sala hacía una especie de paseo; después, retrocediendo, volvía al lugar en que había comenzado y hacía otro paso nuevo, y así continuaba con diversos floreos muy agradables a los que los presenciaban» (Carreras, 1988, tomo II, p. 204).

En Navarra hay constancia de otros tres testimonios más sobre alguien que baila la morisca (Maiora, 2019, pp. 21, 114, 134). La primera se localiza en Monreal. Un vecino del pueblo, al ser preguntado en un juicio, recordaba que un domingo de mayo de 1564, «después de cenar, estando muchos mozos y mozas de Monreal y otros vecinos con el tanborín, en la plaza de San Juan, [...] Miguel de Arteiz, que estaba ahí, quiso danzar una morisca, y otros mozos que ahí estaban se lo impedían, y en esto vio [...] que Miguel le quitó la flauta porque no tañese al tamborín, y luego, Joanes [...] le quitó a Miguel la flauta, y le dio al tamborín para que tañese, y de esto, habiéndose agraviado Miguel, vio que tomó su espada». Otro vecino recordaba que la discusión fue «sobre cual había de salir primero a danzar» (AGN-NAO, Tribunales Reales, Procesos, n. ${ }^{\circ}$ 097379, ff. 59v, 66r). El segundo caso sucedió en Abárzuza. En abril de 1578, un vecino recordaba que diez años atrás, más o menos, otro vecino, «en una misa nueva de fray Miguel de Luquin, religioso de Iranzu, habiendo este testigo salido a bailar una morisca, y sin que este testigo diese ocasión alguna, le dijo que no bailase, y porque este testigo le respondió que él no era parte para estorbarle, al cabo de rato después, andando bailando, tiró una puñada al testigo» (AGN-NAO, Tribunales Reales, Procesos, n. ${ }^{\circ}$ 069814, f. 24v). El último caso nos remite a Isaba. Aquí, como en el caso de Sarriguren, uno de los danzaris bailó la morisca con cascabeles en los pies. El 26 de julio de 1607, una testigo declaraba que, al oscurecer, llegaron a su casa de Isaba dos pastores, y que uno de ellos, apellidado Baigorri, «comenzó a hacer son con una mandurria que traía, y al cabo de poco rato vino a la casa [...] Catalina de Salaberri, con otra moza vasca, natural de Santa Engracia, llamada Domenja, [...] y también vinieron en su compañía otros dos vascos, que al uno [...] le llamaban Fardel, y el otro (no) sabe cómo se llamaba, y otros dos mozos de la villa de Roncal, [...] y comenzaron a danzar en la cocina de la casa la morisca Catalina y Domenja con Baigorri y Fardel, haciendo ellos mismos son con las mandurrias que tenían, y Fardel llevaba cascabeles en las piernas». (AGN-NAO, Tribunales Reales, Procesos, n. ${ }^{\circ}$ 266393, f. 81r). En Gerri de la Sal, pueblo de Lleida, se baila una morisca coincidiendo con el último día de las fiestas patronales: «la música de la Morisca se repetía tres veces, la primera servía de introducción y no se bailaba. Con la segunda comenzaba el baile que consta de doce compases. El baile comienza con una vuelta de la bailarina hacia la izquierda. Los tres primeros compases se bailan dándose bailarín y bailarina las manos como en el Ball Plá, variándose de dirección en cada compás, si bien el bailarín gira sobre sí mismo hacia la derecha ejecutando un paso sencillo mientras la bailarina le sigue de frente durante toda la vuelta, haciendo los dos un paso de tacón y punta, dando una patada en la tierra con el pie derecho, que coincide con el último compás. Inmediatamente después (y esto es lo que da carácter a la Morisca) la bailarina huye situándose detrás del bailarín mientras éste realiza unos saltitos con las puntas hasta que se acerca hacia ella para rodearla, que nuevamente huye y se sitúa detrás de él. En el séptimo compás vuelven a darse las manos y bailan tres compases cogidos de ellas y, en los tres últimos compases, se sueltan y vuelve a huir la bailarina. Vuelve luego a repetirse todo hasta resultar los doce compases. En la última nota de cada compás se saludan los dos, dando una patada en tierra con el pie derecho, haciendo sonar los mozos en ese momento, los disparos de sus escopetas que los hacen coincidir con la última nota del compás. Y el baile finaliza así» (Sanz, 1976, pp. 26-27).

12 AGN-NaO, Tribunales Reales, Procesos, n. ${ }^{\circ}$ 010414, f. 36v.

13 AGN-NAO, Tribunales Reales, Procesos, n. ${ }^{\circ}$ 010414, f. 36r. 
La Real Corte dictó sentencia el 7 de junio de 1560. Martín, el juglar, fue condenado a dos años de destierro del reino, a indemnizar con cuarenta ducados a Joanicot y a pagar veintiún florines de gastos judiciales. A su compañero de prisión le condenaron a cuatro meses de destierro de Mendillorri.

El 3 de agosto de 1560, el Consejo Real, además de ratificar la sentencia de la Corte, añadía un plus de crueldad para el juglar: de no pagar la multa en seis días le sacarían desnudo por la ciudad y recibiría cien azotes en público.

El juglar Martín, días después, suplicaba clemencia. Sus bienes se reducían a "un salterio para tañer, el cual ha oído decir que su mujer lo ha empeñado para darle de comer»:

por ser pobre, como lo es, mandaron los del vuestro Consejo, en caso no pagase dentro de un breve término, le diesen cien azotes, y para cumplir lo susodicho le han sacado desnudo por una vez fuera de la cárcel, para ejecutar los azotes, y le han vuelto sin ejecutar aquella, donde ha recibido la misma afrenta que si le dieran los azotes por las calles, y el suplicante tiene mujer e hijos que mueren de hambre por su gran pobreza, y es persona que aunque esté en la cárcel mucho tiempo no lo podrá pagar; suplica a V. M. mande darle libertad y por libre de lo que está condenado, pues ha salido fuera de la cárcel desnudo y ha recibido la misma afrenta ${ }^{14}$.

\subsection{Fiesta de la Ascensión de 1572, Irurita}

El siguiente caso documentado sobre una danza lecayo nos lleva a Irurita. La fecha fue el 15 de mayo de 1572, la Ascensión, día grande del pueblo, jornada en la que muchas personas del valle se acercaban a esta localidad para pasar un buen rato.

Pero aquel día fue diferente. La velada terminó con un herido de puñal, que fallecería una semana más tarde en el palacio de Jauregizar. La Real Corte investigó el caso. Los testigos, interrogados por el juez, recordaban que ese día se bailaron en la plaza dos danzas diferentes: una, la primera, fue un lecayo, guiada por clérigos y palacianas ${ }^{15}$. La segunda danza, a la que no pusieron nombre, la describían como danza de «saltar de corrida», más alegre que el lecayo. Las dos danzas se bailaron en

14 AGN-NAO, Tribunales Reales, Procesos, n. ${ }^{\circ}$ 010414, f. 64r.

15 La participación de párrocos rurales en los bailes fue una costumbre muy arraigada en Euskal Herria hasta finales del siglo XVII. El Concilio de Trento (1545-1563) intentó cortar esta tradición, pero los sacerdotes no hicieron mucho caso. Durante el siglo XVII, el tribunal eclesiástico de la Diócesis de Iruñea investigó numerosas denuncias contra párrocos, acusados, entre otras cuestiones, de bailar con mujeres en las fiestas locales. Un vecino de Zumarraga lo explicaba así en 1652: «es costumbre asentada, observada y guardada en esta villa y provincia de Guipuzcoa, en días de Corpus, San Juan y otras fiestas solemnes, el que el rector y sus beneficiados, el alcalde y regimiento, con sus mujeres, y otros demás vecinos salen a regocijar y hacer festejo [...] sin que ninguno pueda poner dolo en ello». (Archivo Diocesano de Pamplona, C/ 797 - N. ${ }^{\circ} 37$, f. 11v). Pierre Lancre observó la misma costumbre en sus visitas por Iparralde durante los primeros años del siglo XVII: «en todo el país de Laburdi sus cruces suenan y sus sacerdotes danzan, y son los primeros en el baile que se organiza en el pueblo» (Lancre, 2004, p. 48). 
corro abierto compartiendo ambas una norma, no escrita, pero de habitual aplicación en muchos de los actos sociales de la época: la guía de la danza estaba reservada para el estamento nobiliario. Si alguien osaba alterar este orden, la pendencia estaba asegurada $^{16}$.

El 15 de mayo de 1572, la guía de la primera danza, el lecayo, la ejercía el párroco del palacio Jauregizar. Le seguía de la mano la palaciana de Jauregizar, y tras ella, el párroco de Berroeta. A la zaga, un nutrido corro de hombres y mujeres en armoniosa soka-dantza. Tras un espacio de tiempo que los testigos no aclaran, el juglar dejó de tocar la música del lecayo; cambió de ritmo. La nueva melodía, de saltos, más animada y alegre, motivó que palacianas y sacerdotes abandonasen el corro. Pedro Arráyoz, dueño del palacio de Arraioz, fue el nuevo guía. Pero no por mucho tiempo. Un vecino de Elbete, Cristóbal Ascó, presente en la danza en los puestos traseros, decidió salir del corro general (soka-dantza) y capitanear uno nuevo, el suyo, llevándose consigo a buena parte de las personas que participaban en la danza. La afrenta hacia el palaciano de Arraioz fue mayúscula. En medio del revuelo surgió un espectador, Miguel Zozaya, quien recriminó su proceder al vecino de Elbete. Miguel sacó su espada, Cristóbal su puñal, la sangre brotó y la danza llegó a su fin ${ }^{17}$.

Antes de recordar los testimonios de los testigos, haremos un breve repaso a los principales protagonistas de la alterada jornada festiva:

- El párroco de Jauregizar: guiaba la danza lecayo. Abandonó la soka-dantza cuando el juglar cambió de ritmo.

- Pedro Arráyoz: dueño del palacio de Arraioz. Sustituyó al párroco de Jauregizar en la guía de la soka-dantza.

- Cristóbal Ascó: dueño de la casa Askoa (Elbete). Rompió la soka-dantza que guiaba el palaciano de Arraioz y formó un nuevo corro abierto tomando la guía. Hirió de muerte a Miguel Zozaya y se refugió en el monasterio de Urdazubi.

- Miguel Zozaya: hijo del dueño del palacio de Zozaia. Increpó a Cristóbal Ascó por romper la soka-dantza que guiaba Pedro Arráyoz. Recibió un golpe de puñal y falleció una semana después, a consecuencia de la herida, en el palacio Jauregizar (Arraioz).

16 Rilova Jericó (1998, p. 62) afirma que «una ofensa [en la danza] era tanto como ofender a la familia, al linaje y a ese honor que era el símbolo intangible e invisible de la condición de noble. Algo que era preciso reparar inmediatamente, por los medios más contundentes al alcance de la mano y con sangre a ser posible».

17 Las danzas con saltos no eran adecuadas para la nobleza. Ejecutarlas en público les rebajaba al nivel de los labradores. Lancre también las censuró en su libro de 1613: «En Francia hemos comenzado a olvidarla, una vez que hemos reconocido muy oportunamente que ejecutar esa danza y dar esos saltos violentos únicamente corresponde a la gente rabiosa y agresiva. [...] Por eso me complace decir [...] sobre todo a las muchachas jóvenes que se dejan pervertir y embrujar por ese viejo macho cabrío de Satanás: no saltéis, muchachas, no os agitéis, para que ese maldito macho cabrío no corra detrás de vosotras» (2004, p. 175). 
Conocidos los protagonistas, vayamos con el relato.

Pedro Arráyoz, dueño del palacio de Arraioz, de veintisiete años, fue quien sustituyó al párroco de Jauregizar en la guía del corro abierto. Su declaración fue la siguiente:

el día jueves de la Ascensión, después de comer, fue al lugar de Irurita a ver la fiesta y regocijo, [...] y así, a la tardeada, comenzaron una danza a son de tamborín [con] concurso de mucha gente, en corro, llevando la guía el bachiller Jaureguizar, rector del lugar, con la señora del palacio de Jaureguizar, y de seguida luego el rector de Berroeta y este testigo, y otros muchos consecutivamente, uno después de otro; y acabada esta danza, el juglar o tamborín mudó el son y comenzó a tañer otra danza a más prisa, y por ello el bachiller Jaureguizar y señora de Jaureguizar y rector de Berroeta y mujeres que había hasta la mano de este testigo, dejaron la danza, quedando [el testigo] en ella y toda la otra gente que estaba de seguida, y por no entendérsele la danza llamó este testigo a Pedro de Elizondo [...], vecino de Elizondo, que es danzante, y le dijo que hiciese en su mano guía ${ }^{18}$, y así, llevándolo, al cabo de dos vueltas o tres que hicieron por la plaza, a hora de ponerse el sol, vio que en la plaza, sobre algunas palabras u otra causa que tuvieron, no sabe este testigo qué fue ni lo que tuvieron, ni entendió de ellos nada, salvo que Miguel de Zozaya, hijo del señor de Zozaya, herido, y Cristóbal de Ascó, mozo, cuya es la casa de Ascó, con denuedo y furia, arremetieron el uno para el otro, Cristóbal con puñal rancado y Miguel con su espada desenvainada, y a los primeros encuentros se detuvo un poco Miguel de Zozaya, y habiendo hecho una manera de reconocimiento a su persona, arremetió para Cristóbal y tiró una cuchillada hacia los hombros abajo a Cristóbal de Ascó, el cual se iba retirando por la plaza con su puñal y haciendo manparo con él, y a esto saltó este testigo de la danza y tomó en brazos y [empujó] a Miguel de Zozaya, a fin de desviarle y apartar de la cuestión, [...] y le quitó de las manos su espada [...] y con ella volvió para Cristóbal de Ascó, dando la espalda a Miguel de Zozaya, habiéndole dicho que se fuese de allí hacia la casa y palacio de Jaureguizar, y dijo a Cristóbal de Ascó que se detuviese una, dos y tres veces, y sin embargo, él, Tristant de Laborda, Sancho Garciarena y otros, que no sabe quiénes, tiraron muchas cuchilladas a este testigo, [...] hasta que mucha gente concurrió en medio y se partieron, y alguno dio voces que Miguel de Zozaya estaba mal herido en el palacio de Jaureguizar, a donde corrió este testigo y otros muchos ${ }^{19}$.

Pedro terminaba su relato recordando que al llegar al palacio de Jauregizar vio que Miguel tenía "una herida de puñal por mitad de los pechos a la mano derecha", que el barbero de Oronoz le hizo una cura y que luego Miguel hizo confesión, pues tenía "perdida la esperanza de la vida de este mundo».

Cristóbal Ascó, causante de la herida a Miguel Zozaya, se refugió en el monasterio de Urdazubi, evitando así la acción de la justicia.

18 Curiosa información la que aporta Pedro Arráyoz. Se quedó de guía de la danza, pero al no saberla bailar, llamó a un danzari de Elizondo para que se pusiese delante de él y seguirle los pasos. Se podría interpretar que la danza posterior al lecayo sería relativamente nueva en la zona.

19 agn-NAO, Tribunales Reales, Procesos, n. ${ }^{\circ}$ 087580, f. 26r-v. 
Juana Pérez de Ursúa, de veintiún años, fue una de las testigos que más información aportó sobre las dos danzas bailadas ese día en la plaza. Sus padres estaban separados. Ella vivía con su padre en Arraioz. El día de la Ascensión fue a visitar a su madre, que vivía en Irurita. Preguntada por lo sucedido declaraba que:

el día de San Salvador último pasado, por la mañana, llegó a Irurita desde Arráyoz, a la casa de su madre, que vive en Irurita [... ]; fue a la iglesia, a oír los divinos oficios, como la festividad del día y la advocación de la parroquial San Salvador, y comió y estuvo con su madre hasta después de cenar; [después fue] a la plaza de Irurita, y se asentó en el umbral de la puerta de la casa llamada Echeberría, que está junto a la plaza, con otras mozas de Arráyoz y gentes de Irurita y otras partes, y vio cómo el bachiller de Jaureguizar, rector del lugar, tomando en su mano a María de Azpilcueta, mujer de Pierres de Jaureguizar, cuyo es el palacio de Jaureguizar, principiaron danzar a son de un tanborín los lecayos, y en la mano de María de Azpilcueta, por la parte baja, el rector de Berroeta, y después otras mujeres, y en siguiente Pedro de Arráyoz, cuyo es el palacio de Arráyoz ${ }^{20}$.

Juana, en el siguiente párrafo, relata el abandono de sacerdotes y palacianas al cambiar la música a un ritmo más vivo:

Cristóbal de Ascó, acusado, llegó a esta que declara, [... y y tomándola de la mano le dijo que fuese a danzar con él, al son del tamborín y corte, donde andaba danzando el bachiller Jaureguizar y la señora de Jaureguizar y los de suso nombrados, y esta que declara se levantó y siguió a Cristóbal de Ascó a la danza, y entraron los dos en aquella corte, casi en los postreros, y andando de esa manera, al cabo de poco rato, el dicho tamborín mudó los lecayos y principió a tañer otro son y mudanza de saltar de corrida, y en esto quedaron y salieron de la danza el bachiller de Jaureguizar y la señora del palacio y el otro clérigo, quedándose en la delantera [...] Pedro de Arráyoz con otros muchos ${ }^{21}$.

\section{Acto seguido:}

Cristóbal de Ascó, acusado, se dividió y apartó por sí, teniendo a esta que declara de la mano, de la otra gente que iba más adelante que él [...] y al son y mudanza de saltar principiaron todos, y vio como luego acudió [...] Miguel de Zozaya, estudiante, y que se acercó a Cristóbal y dijo al oído algunas palabras, que esta que declara, a la que iba en su mano y como iban saltando al son del tamborín con mucha furia no oyó ni comprendió lo que le dijo, mas vio cómo Miguel de Zozaya, difunto, puso el dedo en la cara, cabe la nariz, haciendo ceño o señal de desafío ${ }^{22}$.

Otro de los interrogados por el juez de la Real Corte fue el pelaire de Irurita Sancho Arráyoz, de treinta años. Recordaba que el día de la Ascensión «llegó mucha gente de otros lugares circunvecinos a regocijarse y holgar, como lo suelen hacer otros años».

20 AGN-NaO, Tribunales Reales, Procesos, n. ${ }^{\circ} 087580$, f. $6 r-v$.

21 AGN-NAO, Tribunales Reales, Procesos, n. ${ }^{\circ} 087580$, f. 6r.

22 AGN-NAO, Tribunales Reales, Procesos, n. ${ }^{\circ} 087580$, f. 6v. 


\section{Por la tarde:}

antes que escureciese, un rato después que la gente cenó, salieron a la plaza los tanborines y principiaron a tañer los lecayos; [...] el bachiller de Jaureguizar [...] tomó de la mano a María de Azpilcueta, señora del palacio de Jaureguizar, y principió a danzar los lecayos delante de todos, y en la mano de María de Azpilcueta, por la parte más baja, el rector de Berroeta, y en siguiente otras mujeres casadas, y en siguiente de ellos Pedro de Arráyoz, cuyo es el palacio Arráyoz y otros muchos, y entre ellos Cristóbal de Ascó, [...] y todos danzaron un rato los lecayos, con mucha templanza y alegría, sin ningún enojo y alteración; [poco después] los tanborines mudaron los lecayos a otro son y danza de saltar, y a esto vio este testigo que los dos rectores y la señora del palacio salieron de la danza y subieron a las ventanas de la casa de Guerunburua [...] quedándose Pedro de Arráyoz por guía de todos los demás que danzaban al son de saltar ${ }^{23}$.

Como se puede comprobar, la «templanza» del baile lecayo era apropiada para la nobleza; no así el «saltar» de la segunda danza.

\section{El pelaire continuaba su relato:}

Cristóbal de Ascó, acusado, tomó de la mano a una hija de Sancho de Ursúa, llamada Juana Pérez, y principió a danzar tomando la guía, [...] y sobre esta división [...] Miguel de Zozaya le dijo algunas palabras [a Cristóbal] que este testigo, como andaba danzando con la gente que Pedro de Arráyoz llevaba, no comprendió ni las pudo comprender, porque iban de corrida, más que oyó decir en la plaza a muchos hombres [...] que Miguel de Zozaya dijo a Cristóbal de Ascó que si le parecía bien lo que hizo en dividirse de la danza y tomarse la guía donde danzaba un gentil hombre hijodalgo como Pedro de Arráyoz, que no había hecho bien ni le pareció bien, y que Cristóbal le respondió que él era tan hijodalgo como otros cualesquiera para danzar en la plaza, y [Miguel de Zozaya] le dijo que no había hecho bien y que él le haría quedar, y como tenía la espada en las manos, echó mano a ella y rancó hasta la mitad, y en esto [...] Cristóbal de Ascó echó mano a un puñal que llevaba en la cinta, y rancado con él, dando un salto, arrojó a Miguel de Zozaya un golpe a manera de estocada y le dio con él en los pechos, encima de la tetilla derecha, con que le cortó el sayo, jubón y camisa, cuero y carnes, y trajo del golpe efusión de sangre ${ }^{24}$.

23 AGN-NAO, Tribunales Reales, Procesos, n. ${ }^{\circ} 087580$, f. 8r.

24 AGN-NAO, Tribunales Reales, Procesos, n. ${ }^{\circ} 087580$, f. 8v. En esta época (s. XVI-XVIII), la nobleza aprovechaba todos los actos sociales para exhibir sus privilegios heredados del periodo medieval. Además de capitanear las danzas, otro de los espacios más codiciados por estas élites fue el ámbito religioso. Sentarse en el primer banco de la iglesia, ser el primero en recibir la paz o capitanear las procesiones después del párroco fueron privilegios que los palacianos y sus familiares cercanos intentaron mantener vigentes frente a la protesta popular en muchos pueblos de Navarra (Orduna, 2009, pp. 239, 264). No hay que olvidar que tanto las misas en días de fiesta como los bailes populares eran actos a los que concurría todo el pueblo, y es allí, ante los ojos de la comunidad, donde la nobleza se esforzaba en mostrar que pertenecía a una clase superior. 
Joanot Arreche, dueño de la casa Iturregi, ratificaba lo dicho por los testigos anteriores, afirmando que la festividad de la Ascensión «es la vocación de la parroquial de Irurita y en cada un año suelen venir al lugar muchos vecinos y gente de los otros lugares circunvecinos, a casa de sus parientes, y a holgar, como vinieron el dicho día [...] y hubo muchas danzas y otros regocijos, en las cuales holgaron las gentes sin ningún enojo ni alteración».

En su relato de lo sucedido, recordaba también que la danza que siguió al lecayo fue una danza de saltos:

al cabo de rato que danzaron los lecayos, el rector y los otros que danzaban hasta la mano de Pedro de Arráyoz quedaron, de manera que Pedro de Arráyoz quedó la guía de toda la danza y corte que a la sazón andaba en la plaza, y los tamborines mudaron el son de los lecayos a otro son de saltar corriendo, y a esta mudanza de son vio este testigo que Cristóbal de Ascó se dividió y apartó de la compañía y corte que Pedro de Arráyoz guiaba, [...] llevando de la mano a Juana Pérez, hija de Sancho de Ursúa, vecino del lugar de Arráyoz ${ }^{25}$.

La conversación entre agresor y agredido, según Joanot Arreche, fue la siguiente:

[Zozaya] dijo a Cristóbal de Ascó, acusado: ¡Oh bellaco, vos habéis de danzar ahí andando ahí un gentil hombre hidalgo como Pedro de Arráyoz!; y el acusado le dijo: ¡Yo soy tan hijodalgo como otros que andan aquí para danzar, y si algo quisiere de él, vos y yo nos toparemos!; y diciendo las dichas palabras Cristóbal prosiguió adelante la danza, llevando en su mano a Juana Pérez, y dio tres o cuatro vueltas ${ }^{26}$.

Uno de los últimos testigos en prestar declaración, Juan Echeberría, zapatero de veinticinco años, confirmaba que «los juglares mudaron el son de los lecayos a otro son de saltar yendo corriendo", momento en el que "Cristóbal de Ascó, acusado, se dividió y apartó por sí de la compañía que Pedro de Arráyoz guiaba, tomando en su mano a Juana Pérez de Ursúa, y otras muchas mozas, guiándolas de la parte de tras de la gente que Pedro de Arráyoz llevaba, donde andaba este testigo ${ }^{27}$.

Las consecuencias de la agitada noche las relataba Juanot de Arreche:

se publicó en toda la plaza y lugar de Irurita que Miguel de Zozaya quedaba muy mal herido de una puñalada que le había dado [Ascó] en los pechos, en la parte derecha, de la cual murió, según por público se dijo, en el lugar de Arráyoz, en casa de Pedro de Arráyoz, y su cuerpo fue enterrado en la iglesia del lugar de Oyeregui, de la valle de Bertiz, y que después acá anda ausente el acusado y que ha estado retraído en el monasterio de Urdax ${ }^{28}$.

25 AGN-NAO, Tribunales Reales, Procesos, n. ${ }^{\circ} 087580$, f. 11v.

26 AGN-NAO, Tribunales Reales, Procesos, n. ${ }^{\circ} 087580$, f. 12 r.

27 AGN-NAO, Tribunales Reales, Procesos, n. ${ }^{\circ} 087580$, f. 16v.

28 AGN-NAO, Tribunales Reales, Procesos, n. ${ }^{\circ} 087580$, f. 11v. 
Las investigaciones de la Real Corte quedaron sin sentencia. La pista sobre Cristóbal Ascó desapareció tras su huida al monasterio de Urdazubi.

\subsection{Día de la Ascensión de 1585; Irurita ${ }^{29}$}

La siguiente danza lecayo nos acerca también a Irurita, aunque en esta ocasión, por desgracia, los testimonios de los vecinos son más escuetos. Corría el año 1585. El día elegido para el baile fue de nuevo el día de San Salvador (Ascensión), advocación de la iglesia local, celebrado ese año el 30 de mayo ${ }^{30}$. Habían transcurrido trece años desde los incidentes del capítulo anterior. La danza lecayo, presente en la fiesta, no contó, al parecer, ni con sacerdotes ni con representantes de la alta nobleza.

La información sobre la jornada proviene, como el caso anterior, de un proceso judicial iniciado por el alcalde de Baztan pero que terminó en manos de la Real Corte. El fiscal del reino y Joanes Indabere, vecino de Ziga, acusaron a un vecino de Irurita, apellidado Oyargüen, de haber propinado una cuchillada al propio Joanes Indabere. El motivo de la discusión, y del posterior cruce de cuchilladas, fueron las prisas por danzar que tuvieron unos mozos de Irurita mientras bailaba la cuadrilla de Ziga ${ }^{31}$.

El primer vecino en testificar ante el juez fue el juglar de los mozos de Ziga Joanot Mendiondo, de veinte años. De su testimonio se podría destacar el número de danzaris que protagonizaron el baile, unas cuarenta personas «hombres y mujeres, casados y por casar», y que las cuadrillas de jóvenes contrataban a los juglares por un año ${ }^{32}$. También recordó que la danza bailada aquel día fue un lecayo:

el día referido fue la vocación de la iglesia parroquial de Irurita, y suelen ser y fueron las mecetas del lugar, a donde acostumbran acudir a holgar muchas gentes de los pueblos comarcanos, como acuden y van por toda la tierra de un lugar a otro en los

29 Este proceso judicial fue brevemente citado por Florencio Idoate (1979, pp. 330-331).

30 El día de San Salvador, advocación de la iglesia de Irurita, coincidía con el día de la Ascensión, según testificó el vecino de Lekaroz Miguel Plaza: «el día de San Salvador del año de 1585 [...] este testigo se halló presente en el lugar de Irurita, porque suelen, de un lugar a otro, ir los vecinos del valle a mecetas, y el dicho día de la Ascensión es la meceta de Irurita, y los vecinos del valle se recogieron a holgar y regocijar la fiesta, y después de comer, en la plaza, principiaron a danzar muchos hombres y mozos los lecayos y otras danzas al son de un juglar que les hacía son» (AGN-NAO, Tribunales Reales, Procesos, n. ${ }^{\text {o }}$ 028860).

31 En esta ocasión, el altercado nada tuvo que ver con quién encabezaba la danza, cuestión que, aunque importante, no sería tan estricta si la nobleza se ausentaba de la soka-dantza. Como apunta Sánchez Ekiza para fechas posteriores $(1999$, p. 113) «estaba claro que la soka-danza o aurresku se bailaba muchas veces al cabo del año. Y, si bien es cierto que encabezarlo siempre suponía un honor, el protocolo no era el mismo si realmente bailaban alcalde y concejales, si de lo que se trataba era simplemente de la elección del mayordomo [...] o si lisa y llanamente se correspondía con un domingo cualquiera del año».

32 La contratación de juglares por un año era algo habitual en el valle. En 1614, en Arizkun, los mozos solteros pleiteaban contra los regidores por este tema: «de siempre acá los mozos por casar [...] han estado en uso continuo, en cada un año, de concertar un juglar para su entretenimiento, y con el son de él han danzado por las plazas del lugar» (AGN-NAO, Tribunales Reales, Procesos, n. . 014046, f. 1r). 
días de las mecetas de cada lugar, y así acudió el quejante [...] con [varios vecinos de Ziga] y anduvieron danzando y holgándose con mucho regocijo y placer, haciéndoles este testigo son con su atanbor y flauta, como juglar suyo y alquilado por ellos, porque por Pascua de Resurrección próximamente pasada le alquilaron por un año, y así les hizo son a ellos, como les hicieron otros juglares a otros vecinos de pueblos comarcanos, como lo tienen uso y costumbre, sin que por ello los vecinos del tal pueblo se puedan ni tengan de qué agraviarse, por ser cosa que por toda la tierra se practica, y a hora de vísperas, estando este testigo haciendo son y danzando en la danza que llaman lecayo [...] muchos hombres y mujeres casadas y por casar, hasta cuarenta y más, en la plaza pública de Irurita, llegó para este testigo Joanes de Oyargüen, acusado, y le dijo que acorzase el son y callase en breve ${ }^{33}$.

El juglar afirmaba que ignoró las amenazas de Oyargüen, pues los jóvenes de Ziga le dijeron que siguiese con la música. Mientras tanto, Oyargüen:

estaba parado al par de este testigo, [...] con puñal en cinta mirando a los danzantes, y a lo que iba acabando el son, a muy poco rato que pasaron las palabras susodichas, [...] por detrás le dio un puntapié en el atanbor, y con esto paró el son, con entender que le había reventado, y luego se dejaron de la danza los danzantes y comenzaron revolverse, y este testigo, pareciéndole mal [...] dijo a [Oyargüen] que por qué había hecho aquello, el cual, tratándolo de bellaco, echó mano al puñal que llevaba en la cinta contra este testigo y rancó aquel, y también este testigo su puñal que tenía en la cinta contra él, y a esta sazón cargaron sobre ellos muchos de los danzantes [...] y los detuvieron a que no se hiriesen, y comenzaron a reprender a [Oyargüen] diciéndole que había hecho mal y que por qué causa había de hacer aquello, y [Oyargüen] arremetió contra los que le reprendieron con su puñal rancado en la mano, y en tropel cargaron sobre él muchos de los danzantes, a puñaladas y golpes, y revueltos de esta manera se desvió este testigo de ellos con su atanbor, y luego se hicieron cinco o seis bandos a una parte y a otra, con muchas espadas y puñales rancados, unos en favor de otros, [... . y luego se atravesó Sancho de Iturbide, alcalde, con apellidar la voz del rey, y así los apartó de la furia y revuelta en que se pusieron ${ }^{34}$.

Desgraciadamente, los testigos no aportaron más información sobre el baile. La mayoría confirmaron lo dicho por el juglar, como el vecino de Irurita Joanes Dolagaray:

a hora de medio día, luego en comiendo, a lo que salió a danzar toda la gente, comenzó a hacer son de lecayo Joanot Mendiondo, juglar [...], con su atanbor y flauta, y comenzó a danzar tomando guía uno llamado Miguel Aroz, vecino de Ciga, y con él hombres y mujeres treinta personas y más, y en el cabo Juan Pérez Inda [...] y alrededor y por toda la plaza mucha gente, y entre otros el alcalde del valle, con el de Subizar y otros caballeros, y al cabo de poco rato, estando el juglar haciendo son y

33 AGN-NaO, Tribunales Reales, Procesos, n. ${ }^{\circ} 028860$, f. 6r-v.

34 AGN-NAO, Tribunales Reales, Procesos, n. ${ }^{\circ} 028860$, ff. 6v, 7r. 
la gente danzando y entrando en la danza, vio este testigo dar el acusado al juglar, en el atanbor con que hacía son, con el pie levantándolo, un puntapié, como quien hacía menosprecio de los danzantes y en agravio de ello: ${ }^{35}$.

La sentencia llegó el 27 de marzo de 1586, casi un año después del altercado. Joanes Oyargüen fue condenado a seis meses de destierro.

\subsection{Romería de Arrate de 1620, Eibar $^{36}$}

El último documento encontrado que trata sobre una danza lecayo, aparece en un informe municipal de Eibar fechado el lunes 14 de septiembre de 1620. Ese día, el alcalde de Eibar, Pedro Orbea, junto con el escribano municipal, Cristóbal Sugadi, interrogaron a un joven de Elorrio, Juan Olaso, sobre los incidentes ocurridos en la ermita de Arrate el martes anterior, 8 de septiembre, festividad de la virgen de Arrate, y sobre lo que sucedió el domingo siguiente, 13 de septiembre.

El resumen de lo sucedido podría ser el siguiente: el martes 8 de septiembre de 1620, siguiendo la tradición, los vecinos

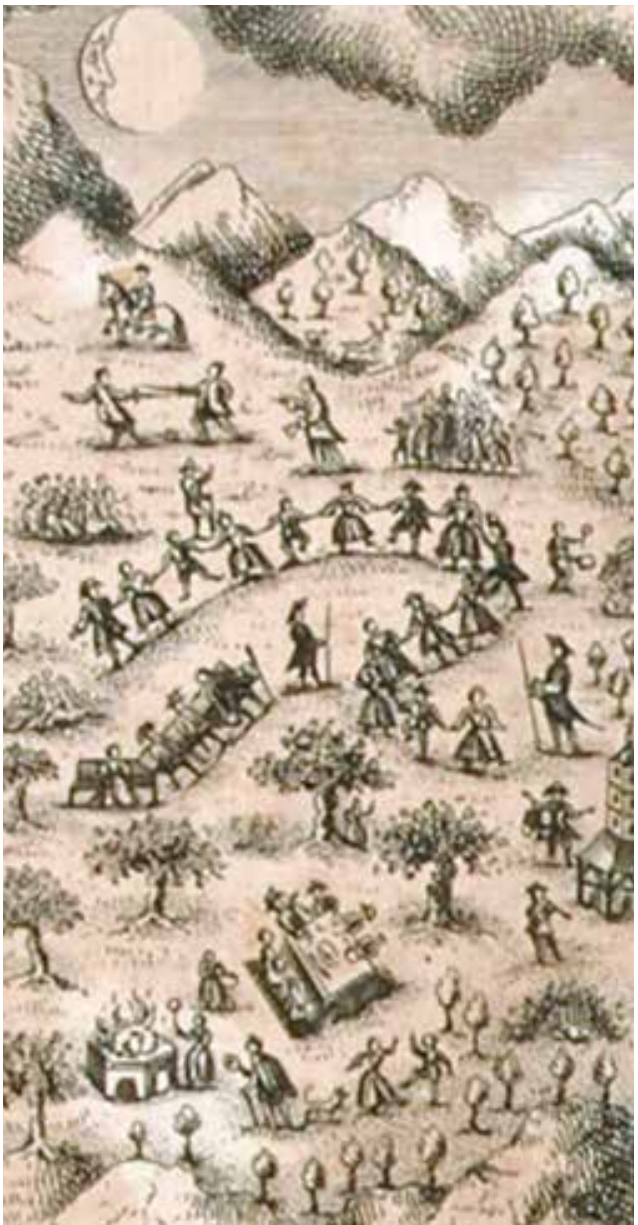

Figura 7. Detalle del grupo danzari de la figura 6 (fuente: Museo de San Telmo, Donostia). En este caso los participantes en la danza parece que no siguen un patrón fijo a la hora de danzar cara adentro o hacia el exterior. de la zona acudieron a la ermita de Arrate. En el transcurso de la jornada hubo algún leve altercado entre los mozos de Eibar y los de Elgoibar. El alcalde de Eibar detuvo a dos jóvenes de Elgoibar pero los soltó al no haber delito de sangre. El domingo siguiente, 13 de septiembre, los vecinos de ambos lugares volvieron a la ermita en romería. Tras los oficios religiosos, a eso de las cinco de la tarde, algunos vecinos de Elgoibar formaron una danza lecayo. A partir de aquí, y por motivos que no quedan muy claros, los jóvenes de ambos pueblos comenzaron a discutir. El balance final habla de «heridos y mucha efusión de sangre».

35 AGN-NAO, Tribunales Reales, Procesos, n. ${ }^{\circ} 028860$, f. 7r.

36 La noticia de esta pendencia la dio Yolanda Ruiz, archivera del Archivo Municipal de Eibar, en el ejemplar del año 2010 de la revista Eibar herriaren arima. 
La información que aporta el testigo de Elorrio sobre la danza lecayo es escasa. Se reduce a decir que se bailó y que estaba compuesta solo de hombres.

El testimonio fue el siguiente:

ayer domingo, que se contaron 13 [...] la villa de Eibar y cofrades de la cofradía de la ermita, como tiene de costumbre, celebró la colación de la cofradía, con mucha paz y quietud, asistiendo el alcalde y yo, el presente escribano, y otras muchas personas, y después de todo esto, como a las seis de la tarde, poco más o menos, habiéndose venido el alcalde, estando este testigo en compañía de algunos vecinos de Elgoibar, y entre ellos uno que se llama San Juan de Hiumendi [...], llegó a ellos un mancebo, que por mal nombre le llaman Comino, que es hermano del dicho San Juan, al cual, y a los demás que con él estaban, les habló al oído estando jugando, y todos, fuera de uno, se levantaron del juego y fueron unos tras otros, y vio cómo una cuadrilla de los dichos vecinos de Elgoibar, que eran más de treinta, armaron una danza que llaman lecaio como es costumbre sin que hubiera mujeres, y [...] sin saber ni entender este testigo cómo ni por qué se levantó un ruido y pendencia, en la cual todos los vecinos de Elgoibar echaron mano a las espadas y comenzaron a acuchillar a cuantos topaban vecinos de Eibar, con muy gran cólera y rabia, de manera que al que topaban, que les parecía que era de Eibar, le acuchillaban y le seguían diciendo muera muera que es de Eibar, de suerte que no había quién se les opusiese, y los que acudieron a querer remediar y poner paz eran luego perseguidos, [...] y los seguían hasta la iglesia, que era lástima de ver la furia con que andaban; [... y fue de suerte que habiendo entrado algunos en la iglesia, por guarecerse, fueron tras ellos a querer ejecutar su mal intento, y según es notorio, quisieron poner manos en Andrés, abad de Azaldegui, [...] porque les quiso estorbar, y al fin cerró las puertas, las cuales los vecinos de Elgoibar quisieron abrir [...] y como vieron tan grande atrevimiento en ellos, alguno repicó la campana, y entonces se huyeron, y ha oído decir este testigo que hubo heridos también de los de la parte de Elgoibar.

El testigo afirmaba que el origen de la discusión entre las cuadrillas de Eibar y Elgoibar fue:

un mancebo que se llama Juan de Zutuneguieta, casero, vecino de Eibar, con quien dicen tenían en ojo y procuraban sacudirle, y que se escapó huyendo de ellos de la danza de lecayo, donde también dicen anduvo con ellos ${ }^{37}$.

\section{SIGNIFICADO DE LECAYO}

Relacionar lecayo con lacayo sería, quizá, la forma más sencilla de encontrar un significado al nombre de la danza. Pero esta opción parece difícil de aceptar cuando se comprueba que ninguno de los documentos, en donde se cita la danza, aparece escrita

37 Eibarko udal artxiboa. Eskribautza Funtsa. Sig. C/291-14. La transcripción del original está realizada por Yolanda Ruiz Urbón y se puede consultar en: https://dantzan.eus/albisteak/arrate-1620-dokumentu-originala 
como lacayo. Siempre se escribe con E en vez de con A (lecayo, no lacayo). Aun así, si nos aventurásemos a emparentar lecayo con lacayo, tampoco hay una danza de la época tardomedieval ni del Renacimiento con ese nombre, o por lo menos no aparece así citada en ninguno de los libros ni manuscritos que tratan sobre la danza en estos siglos ${ }^{38}$. Forzando la cuerda en esta dirección, se podría identificar lacayo con villano, por el significado parecido de ambas palabras. Entonces sí que estaríamos ante una danza conocida, el villanico o villanos, pero la descripción que se conoce de esta danza no coincide con la danza que aparece en los documentos de Irurita o de Eibar. El villanico, según explica Rodríguez (2015, p. 124), es una «danza rústica española que fue muy popular durante el siglo XVII. La versión de Cesare Negri es la más antigua que se conserva y pertenece realmente por su estilo al siglo XVI. Debe ser danzada en círculo por una doble pareja que efectúa cambios entre sí» ${ }^{39}$.

Otra opción para buscar el significado de lecayo, igual de válida que la anterior, sería acudir al idioma hablado por los danzaris: el euskera. Remitiéndonos al Orotariko Euskal Hiztegia de Euskaltzaindia, encontramos lekaio como sinónimo de irrintzi («alaitasun oihua»). De esta manera, tendríamos una danza que, por lógica, al llamarse lekaio, debería contar con algún irrintzi en alguna parte de su ejecución. En los testimonios de Irurita y Eibar no consta ningún grito de alegría, lo que no quiere decir que no lo hubiera.

Por último, en el mismo diccionario de Euskaltzaindia encontramos un nuevo significado para lecayo, esta vez relacionado con el nombre de la villa costera de Lekeitio: «Lequeitio, dicho de antes Lecaitegui por los muchos hombres [...] baldíos y malhechores, llamados antiguamente lekaiak, y en castellano 'lecayos', que allí se acogían». Esta opción parece llevarnos de nuevo al emparejamiento lecayo-villano, villano-malhechor. ¿Podría ser la danza lecayo una danza que tuviese su origen en algo relacionado con malhechores (villanos)? ${ }^{40}$ Es posible, aunque la participación de las élites locales en la danza, como se ha demostrado en el presente artículo, parece apuntar hacia otras direcciones.

\section{CONCLUSIONES}

En el presente trabajo se da noticia de tres tipos de danza que se bailaban en Vasconia durante el siglo XVI: la morisca, el lecayo y una danza de «saltar de corrida» a la que los informantes no ponen nombre.

38 Ernestina Rodríguez (2015) realiza un detallado repaso a la práctica totalidad de publicaciones sobre música y danza del Renacimiento, tanto libros impresos como manuscritos, tratados y códices, y en ninguno de ellos aparece mención alguna a una danza conocida como lecayo.

39 Mabel Dolmetsch (1975, p. 82), citando también a Negri, apunta que en la danza de villanos hay una parte que la bailan solo hombres y otra solo mujeres, por lo que no coincide con lo que sabemos del lecayo.

40 Como último dato quedaría la utilización de la palabra lecayo como alias de una persona. En 1554, el vecino de Tafalla Pedro Osés, «alias Lecayo», pleiteaba contra otro vecino por la pertenencia de unas tierras (AGNNAO, Tribunales Reales, Procesos, n. ${ }^{\circ}$ 321263). 
El lecayo es una danza muy poco documentada, que se podía bailar en pareja o en corro abierto. En ella participaba la nobleza junto a las clases populares (juntos pero no mezclados). Las mujeres, casadas y solteras, se juntaban con hombres, casados y solteros. En el caso de Irurita, fechado en 1572, es evidente que la danza lecayo formaba parte de una coreografía mayor: al lecayo le seguía una danza viva y alegre, de saltos, siendo este el primer caso documentado de una sucesión de distintas danzas en Vasconia. En la romería de Arrate, en 1620, la danza lecayo fue protagonizada solo por hombres, aunque en el grabado del siglo XVIII de esa misma fiesta, posiblemente una danza de lecayo, aparece una mujer guiando la danza, siguiéndole en la soka tanto mujeres como hombres.

La danza que siguió al lecayo en Irurita en 1572, y también quizás en 1582, aunque no se puede saber porque la trifulca lo impidió, era una danza alegre, de «mucha furia» y de "saltar de corrida», según los testigos, que no dejaba escuchar lo que la gente hablaba, no apta para que la bailase la nobleza. Este testimonio sería el más antiguo sobre una danza de saltos en Euskal Herria. Otro aspecto a destacar, sobre todo en un entorno como el baztanés, donde hoy en día se dan debates sobre si la mujer debe participar en algunos bailes, sería la evidencia de su participación en pleno siglo XVI.

Por último tenemos las cuatro referencias a la danza morisca, un baile muy extendido por todo Europa en aquellos años. La distancia geográfica de los lugares en donde aparece esta danza (Abárzuza, Sarriguren, Monreal e Isaba), da cuenta de que su práctica debía ser bastante común en todo el reino durante el siglo XVI. Los testimonios que hablan de cascabeles en los pies al danzar la morisca llevan la imaginación al fresco del palacio de Óriz, donde nos encontramos a varios jóvenes desnudos danzando a son de tamboril y portando cascabeles en los pies ${ }^{41}$.

Esperemos que nuevas investigaciones aporten más información sobre estas y otras danzas.

\section{LISTA DE REFERENCIAS}

Alonso y García del Pulgar, T. \& Napal Oteiza, A. (1991). Iconografía musical de Navarra. Merindad de Estella, 1. Cuadernos de Sección. Folklore 4. San Sebastián: Eusko Ikaskuntza.

Carreras y Candi, F. (1988). Folklore y costumbres de España, Tomo II. Madrid: Ediciones Merino.

Diccionario Enciclopédico Espasa (1978). Tomo 3. Madrid: Espasa-Calpe, S. A.

Dolmetsch, M. (1975). Dances of Spain and Italy from 1400 to 1600. New York: Da Capo.

41 Este friso, según Sánchez Cantón (1944), está elaborado durante el último tercio del siglo XVI, años en los que, como hemos comprobado, la morisca se bailaba por toda Navarra. 
Idoate Iragui, F. (1979). Rincones de la historia de Navarra, Tomo I. Pamplona: Aramburu.

Jusué Simonena, C. (coord.). (1994). La catedral de Pamplona. Tomo 1. Pamplona: Caja de Ahorros de Navarra.

Lancre, P. (2004). Tratado de brujería vasca. Descripción de la inconstancia de los malos ángeles o demonios. Tafalla: Txalaparta.

Martínez de Lagos Fernández, E. (2007). Ocio, diversión y espectáculo en la escultura gótica. Bilbao: UPV/EHU.

Orduna Portús, P. M. (2009). Honor y cultura nobiliaria en la Navarra moderna (siglos XVI-XVIII). Barañáin: EUNSA.

Quintanilla González, R. E. (2018). Evolución de las danzas circulares y entrelazadas hasta el final de la Edad Media. Crónica de Córdoba y sus pueblos, 24, 229-280.

Rilova Jericó, C. (1998) El honor de los vascos. Donostia: Hamazazpigarren zalduna.

Rivas González, F. A. (2002). Fuentes iconográficas en el románico aragonés para el estudio de la danza. Seminario de Arte Aragonés, 49-50, 25-57.

Rodríguez Vallés, E. (2015). La escritura de la danza. Evolución histórica de la escritura de la danza entre los siglos XV y XVII (tesis doctoral). Universidad de Valencia.

Ruiz Urbón, Y. (2010). Las fiestas de Arrate de 1620, Eibar herriaren arima, 97, 32.

Sánchez Cantón, F. J. (1944). Las pinturas de Óriz y la guerra de Sajonia. Iruña: Institución Príncipe de Viana.

Sánchez Ekiza, C. (1999). Del danbolín al silvo. Txistu, tamboril y danza vasca en la época de la Ilustración. Pamplona: Euskal Herriko Txistulari Elkartea.

Sanz Romero de Castellón, M. ${ }^{a}$ E. (1976). La «morisca»: baile de Gerri de la Sal. Narria; Estudios de artes y costumbres populares, 2, 26-27.

Sola Ayape, C. (2010). La ermita de San Zoilo de Cáseda. Torres de Elorz: Asociación Cultural Ermita de San Zoilo.

Tovar, A. \& Agud, M. (1993). Diccionario etimológico vasco. Donostia: Gipuzkoako Foru Aldundia. 